\title{
Analysis on Rural and Urban Employee Job Satisfaction towards SBI Bank in Rayalaseema Division
}

\author{
Obulesu Varikunta, M. Sudheer Kumar, K. Kishore Naidu
}

\begin{abstract}
Job satisfaction, in simple words is the level of content with the job an employee is in. Since many years in numerous studies have been conducted on the level of rural and urban employees of job satisfaction in the organization. Job satisfaction is the favorableness or un-favorableness with which employees view their work. Rural and urban Job satisfaction is a psychological concept and it is mostly depend upon the internal feeling of employees. Job satisfaction is a general attitude which is the result of many specific attitudes in these areas. The gradual preeminence of employee in the power hierarchy, overcoming workplace discrimination in the corporate sector displays not the change in the outlook and the perception of the management, job satisfaction of the employees in the State Bank of India.
\end{abstract}

Index Terms: Banking sector, Employees, Rural and urban job satisfaction, Human resource.

\section{INTRODUCTION}

When people speak of employee attitudes them usually Rural and Urban job satisfaction, which describes a positive feeling about a job, resulting from an evaluation of its characteristics. A person with a high level of job satisfaction holds positive feelings about his or her job, while a person with a low level holds negative feelings. (Robins \& Judge, 2013). But defining job satisfaction is not as easy as it seems. This is because job satisfaction is purely related to employees of the organization and with the ever changing corporate dynamics it is becoming very difficult to keep employees satisfied with their jobs.

Therefore it is very important for organizations to design their jobs in such a manner that the employees remain satisfied with their jobs. Along with that it is even more important for organization to continuously measure the levels of satisfaction among employees to make sure that employees are happy with their work. If not, then changes in the work environment are imperative. Coming to our next variable - Rural and Urban employee experience is simply the kind of experience an employee has during a job in a particular organization. Employee experience is a very important component of today's corporate world as it creates a word of mouth amongst the work force. If a company has a bad word of mouth regarding employee experiences then obviously no employee would want to stay or apply to that particular organization. Experience of a particular employee contains almost everything he sees or happens to him in the office. Right from canteen, work space provided, superiors, subordinates, job design, to overall work environment everything makes an employee's experience in the organization.

\section{LITERATURE REVIEW}

Lethal (2007) indicate no direct relationship between job satisfaction and level of education. Rural and Urban employees more satisfaction with their job and recognized (teaching) as their ideal profession. Married employees were found to be more satisfied than their unmarried colleagues were. That the employees with higher rank reported less satisfaction and more dissatisfaction than those who were in the lower rank. Neelamegam Mallika (2010), in the research article "Job satisfaction \& Demographic variables is there a link?" analyzed the job satisfaction perceived by 200 Indian overseas bank employees in Tamil Nadu. The study indicates that the job satisfaction perceived by the bank employees is medium and the demographic variables like age, educational qualification,

(Gill, Sharma, Mathur, \& Bhutani, 2012) - The objective of this paper was to analyze the effects of job satisfaction and work experience on employee desire for empowerment. In both the countries India and Canada job satisfaction and work experience enhance the employee's desire for empowerment. The paper showed that all the employees who have high job satisfaction and work experience show a higher desire for getting their needs and demands met regardless of cultural diversity. (Bhandari \& Soni, 2015) - The objective of the study was to analyze the impact of age, gender and experience on work life balance. The questionnaire method was used and the respondents were employees of bank of Baroda, Udaipur. The statistical tools used were Meaning, percentage and Chi square test.

\section{STATEMENT OF PROBLEM}

The present research study aims at studying and analyzing the impact of identified factors that determine or influence the job satisfaction level among employees of banking industry located in Rayalaseema.
Revised Manuscript Received on July 22, 2019.

Mr. Obulesu Varikunta, Research scholar, Dept. of Management studies, JNTUA, RGMCET-Nandyal

Dr. M. Sudheer Kumar, Professor, Dept. of Management studies RGMCET-Nandyal

Mr. K. Kishore Naidu, Asst Professor, Dept. of Management studies, SREC-Nandyal 


\section{OBJECTIVES OF THE STUDY}

The present study is aimed at finding out job satisfaction of bank employees through different dimension and density of satisfaction levels. More specifically the study aims at the objectives as follows.

The following are the objectives of the study:

1. To examine the profile of banks and employees.

2. To study the impact of employee compensation policy of the banks on the job satisfaction of the employees.

3. To evaluate the career advancement plans of the banks in relation to employee satisfaction.

4. To identify the efficacy of the supervisory practices prevalent in the units and examine to what extent they are able to satisfy the employees in their job.

5. To get an in-sight into the working conditions and its influence on better work performance.

6. To study the impact of the job content on the performance as well as satisfaction of the employees.

7. To offer suitable suggestions to initiate job satisfaction measures in banking sector.

8. To find out the satisfaction among employees of Rural and Urban banks regarding job aspects Sex, Age, Educational level, Monthly Income, experience and Leave facilities.

9. To determine the effect of employee experience on job satisfaction of an employee.

\section{RESEARCH METHODOLOGY}

The data and related information for the study will be collected mainly from records in the banks, interviews with employees, managers. Secondary data will be collected from books, journals, reports, websites etc.

\section{Data Collection:}

Primary data: For the purpose of study, 200 employees will be surveyed, to collect their opinions regarding their job satisfaction, working conditions, compensation policy, training and development etc. As many as 200 employees will be selected from Rayalaseema area. Informal discussions have will also be held with the executives and doctors.

Secondary data: In order to gain insights into the subject, the secondary data and information will be collected from various research papers/articles published in various magazines, journals and data made available to the public by various web sites.

\section{Sample Size}

The sample size is 200 respondents from the study of rural and urban areas. Equal weightage is given to both rural and urban areas banks. That means 100 respondents from rural area banks and remaining 100 respondent's urban area banks namely as the State Bank of India in Rayalaseema division.

\section{Analysis and Interpretation of Data}

In this explanation above the table is overall taken the two hundred employee of sampling to the gender wise it take the hundreds of the employees in rural are and hundreds of the employees taken the Urban area of the people. In this rural area of the sample sixty eight percent of the Male employees and thirty two percent of Female employees taken the gender sampling of rural area of SBI Banks. Above the table of the gender of sapling taken by fifty four percent of the employees

in the Male employee of the urban areas and only forty six percent of the Female employees to taken the sample of urban area SBI bank employees.

Table 1 Rural and Urban Area banks Gender wise sampling

\begin{tabular}{|l|l|l|l|l|}
\hline & \multicolumn{2}{|c|}{ Rural Area Banks } & \multicolumn{2}{c|}{ Urban Area } \\
Banks \\
\hline Area & $\begin{array}{l}\text { No.of } \\
\text { responden } \\
\text { ts }\end{array}$ & $\begin{array}{l}\text { Percentag } \\
\text { e }\end{array}$ & $\begin{array}{l}\text { No.of } \\
\text { responden } \\
\text { ts }\end{array}$ & $\begin{array}{l}\text { Percentag } \\
\text { e }\end{array}$ \\
\hline Male & 68 & $68 \%$ & 54 & $54 \%$ \\
\hline $\begin{array}{l}\text { Femal } \\
\text { e }\end{array}$ & 32 & $32 \%$ & 46 & $46 \%$ \\
\hline Total & $\mathbf{1 0 0}$ & $\mathbf{1 0 0} \%$ & $\mathbf{1 0 0}$ & $\mathbf{1 0 0} \%$ \\
\hline
\end{tabular}

Table 2: Rural and Urban Area banks employees Age groups

\begin{tabular}{|c|c|c|c|c|}
\hline & Area Bank & ural & Banks & n Area \\
\hline Age & $\begin{array}{l}\text { No. of } \\
\text { responden } \\
\text { ts }\end{array}$ & $\begin{array}{l}\text { Percenta } \\
\text { ge }\end{array}$ & $\begin{array}{l}\text { No. of } \\
\text { responden } \\
\text { ts }\end{array}$ & $\begin{array}{l}\text { Percenta } \\
\text { ge }\end{array}$ \\
\hline $\begin{array}{l}\text { 18-21yea } \\
\text { rs }\end{array}$ & 12 & $12 \%$ & 16 & $16 \%$ \\
\hline $\begin{array}{l}21-35 \\
\text { years }\end{array}$ & 24 & $24 \%$ & 27 & $27 \%$ \\
\hline $\begin{array}{l}35-50 \\
\text { years }\end{array}$ & 39 & $39 \%$ & 32 & $32 \%$ \\
\hline $\begin{array}{l}50-55 \\
\text { years }\end{array}$ & 12 & $12 \%$ & 13 & $13 \%$ \\
\hline $\begin{array}{l}55 \text { Above } \\
\text { Age }\end{array}$ & 13 & $13 \%$ & 12 & $12 \%$ \\
\hline $\begin{array}{l}\mathbf{T} \\
\mathbf{o} \\
\mathbf{t} \\
\mathbf{a} \\
\mathbf{l}\end{array}$ & 100 & $100 \%$ & 100 & $100 \%$ \\
\hline
\end{tabular}

Above table indicates the employees of SBI Banking sector taken the sample of age classification of the employees in the rural and urban bank peoples, in this eighteen to twenty one years of age group employees working as a rural banks twelve percent and sixteen percent of the employees are working in the urban areas of banks, the next level of twenty one to thirty five years age group employees are only twenty four percent and urban areas of the employees twenty seven percent of the people. The next category of the age group is thirty five to fifty five years in this age group is thirty nine percent of the employees in rural areas and thirty two percent of the employees are working in urban areas banks. And fifty to fifty five years age group peoples is working in rural areas only twelve percent and thirteen percent of the employees are working in the urban area banks. And finaly taken the sample of above fifty five years age group of the people is thirteen percent of the employees in rural area banks and twelve percent of the employees are working in the urban area Banks. 
Table 3: Classification based on Educational Qualification

\begin{tabular}{|c|c|c|c|c|}
\hline & Banks $^{\mathrm{Ru}}$ & al Area & Banks $^{\mathrm{Ur}}$ & an Area \\
\hline $\begin{array}{l}\text { Education } \\
\text { al } \\
\text { Qualificati } \\
\text { on }\end{array}$ & $\begin{array}{l}\text { No. of } \\
\text { responde } \\
\text { nts }\end{array}$ & $\begin{array}{l}\text { Percenta } \\
\text { ge }\end{array}$ & $\begin{array}{l}\text { No. of } \\
\text { responde } \\
\text { nts }\end{array}$ & $\begin{array}{l}\text { Percenta } \\
\text { ge }\end{array}$ \\
\hline $\begin{array}{l}\text { Undergrad } \\
\text { uate }\end{array}$ & 12 & $12 \%$ & 16 & $16 \%$ \\
\hline Graduates & 34 & $34 \%$ & 39 & $39 \%$ \\
\hline $\begin{array}{l}\text { Postgraduat } \\
\text { e }\end{array}$ & 28 & $28 \%$ & 25 & $25 \%$ \\
\hline $\begin{array}{l}\text { Professiona } \\
1\end{array}$ & 26 & $26 \%$ & 20 & $20 \%$ \\
\hline Total & 100 & $100 \%$ & 100 & $100 \%$ \\
\hline
\end{tabular}

In this concerned the above table is taken the sample is educational qualification of the rural and urban bank employees in state bank of India in Rayalaseema division, in the regarding undergraduate taken the sample in rural areas twelve percent only and sixteen percent of the employees in urban area banks. The next one is graduate taken the sample is rural areas thirty four percent and thirty nine percent of the employee taken the sample is urban areas, another qualification of the postgraduates taken the sample is twenty four percent of the employees in rural areas and twenty percent of the sample is urban areas employees, finally I have taken the educational sample is professional like a B tech, M tech, $\mathrm{PhD}$, Diploma, M Phil in this sample is twenty six percent of the rural areas and twenty percent of the urban areas employees.

Table 4: Classification based on Monthly salary

\begin{tabular}{|c|c|c|c|c|}
\hline & Area Bank & Rural & Banks & n Area \\
\hline $\begin{array}{l}\text { Monthly } \\
\text { Salary }\end{array}$ & $\begin{array}{l}\text { No. of } \\
\text { responden } \\
\text { ts }\end{array}$ & $\begin{array}{l}\text { Percenta } \\
\text { ge }\end{array}$ & $\begin{array}{l}\text { No. of } \\
\text { responden } \\
\text { ts }\end{array}$ & $\begin{array}{l}\text { Percenta } \\
\text { ge }\end{array}$ \\
\hline $\begin{array}{l}\text { Below } \\
16000\end{array}$ & 15 & $15 \%$ & 17 & $17 \%$ \\
\hline $\begin{array}{l}\text { Rs. } 16,00 \\
0 \text { to } \\
22,000\end{array}$ & 22 & $22 \%$ & 21 & $21 \%$ \\
\hline $\begin{array}{l}\text { Rs. } 22,00 \\
1 \text { to } \\
36,000\end{array}$ & 25 & $25 \%$ & 27 & $27 \%$ \\
\hline $\begin{array}{l}\text { Rs.36,00 } \\
0 \text { to } \\
42000\end{array}$ & 18 & $18 \%$ & 14 & $14 \%$ \\
\hline $\begin{array}{l}\text { Above } \\
\text { Rs.4200 } \\
0 \\
\end{array}$ & 20 & $20 \%$ & 21 & $21 \%$ \\
\hline Total & 100 & $100 \%$ & 100 & $100 \%$ \\
\hline
\end{tabular}

Above the table taken the sample is based on employees salary in rural and urban, in this below sixteen thousand taken the salary employees are fifteen percent of the employees in rural area and seventeen percent of the employees in urban areas, and next level is sixteen thousands to twenty two thousand salary employees twenty two percent of the employee in rural areas and twenty one percent of the employees are working the urban areas, another level is twenty two thousand to thirty six thousand for month salary employees are twenty five percent and twenty seven percent of the urban areas, and thirty six thousands to forty two thousands taken for month salary of the employees are workings eighteen percent in rural areas and fourteen percent of the employees taken the sample is urban areas. The last level of salary taken for month forty two thousands above taken salary employees are taken the sample is twenty percent of the employee in rural areas and twenty one percent of the people to taken the sample is in urban areas.

\section{FINDINGS}

- In the above data based to determine the employees are very dissatisfaction to the present salary levels and not only then increments also there, because of the rural areas employees are very income levels to compare to the urban areas bank employees.

- The present study to identify the employee education qualification of the people to join the banks in more than thirty percent of the people high qualification of the bank jobs, and technical people also more interested to join the bank jobs.

- Above data based to analyze the employees satisfactions is very Lowe percent of the satisfaction of the Banking organization, more than rural areas of the bank employees are some level satisfaction to compere the urban areas bank employees. In this post graduates to join the banking sector and under graduates also to joined the banking sectors.

- More than employees to dissatisfy the our monthly salary, because of lower salary and high work present to the banking sector that's why more number of the employees and having to the determined the more number of the employees at dissatisfaction to the present salary end based on present expensansions.

- Over all the State bank of Indian bank employees are low number of the people to satisfy the job, and high work inventions to the banks present days.

\section{SUGGESTIONS}

In the present situations to develop the banking system in depends on employees job satisfaction not only banking system any organizations. The major problem of banking sector employees are to face more problem in the inside of the banks like an environment working conditions and location of the working, area of working customers behavior like a rural area of the customers are very low literacy in this banks to face more problem of the customers side, to impact to the family intention to the work.in the sense of human beings to develop the organizational activities alos, and management to conduct the training programs in all employees to updates to the updated technology. The banking employees working areas depends on face the problems also mass areas working the employees face the more problems to the customers side and high risk but equal salary to the rural an urban bank employees there is no difference all allowance timing working conditions work intentions everything is same to the rural and urban areas banks. 
The bank employee are low satisfaction main reason in the sense of inner feeling of employees low salary high work, more risk low safety, less benefits to provide the organizations majorly the employees are prepared children education, transportation problems, family problems personal problems and having to determine the employees feeling, in the sense of employee are prepared organizational quarters, provide the education facility to our children and frieze benefits awards rewards and Encourage gifts and compensation prizes to prove the organization. The banking employees everyone to make decision pending to the superior authority to dissatisfy the job, in the present situations are very critical to deal with the organization employees because of the main assent of the organization is employees that's the drawback of the management. Every organization to develop of the market value and share value financial levels social status to depends on our working organization employees.

\section{CONCLUSION}

The purpose of this study was to investigate the predictors of bank employees. Job satisfaction including those that are personal and those that are job related in the Jammu and Kashmir Bank. Job satisfaction has been one of the most extensively researched concepts in work and organizational psychology. The dimensions and degree of job satisfaction of bank employees in SBI Banks with Rayalaseema Division are not uniform. However, after introspecting several parameters and dimensions, it becomes clear that no single dimension or factor can please human being totally. More over satisfaction is a state of mind. Further efficient and talent employees switching over to greener pastures in the private sector can be effectively checked. SBI with a large number of happy workers marching ahead on the road to goal fulfillment can continue to hold aloft the flag of its unassailable top position even in the fiercely fought competition infested banking market if suggestions given in this study are put in to action.

\section{REFERENCES}

1. Robins, S.P., \& Judge, T.P. (2013). Organizational Behaviour. Pearson Education Inc.

2. Khalid Salman \& Irshad Muhammad,( 2011) “Factor Affecting Job Satisfaction” Journal of Management Research, 6(2), 84- 101.

3. Alam (2013) Wages and Employees Satisfaction Management and Labour Studies. 23(3), pp. 421-427.

4. Zeal, Anwar and Nazrul (2012). "Work Experience and relationship with Job Satisfaction". Journal of Psychology, Vol. 132.

5. Neelamegam Mallika (2010), “Job Satisfaction \& Demographic Variables - Is there a Link?", Perspectives of Innovation , Economics \& Business, Volume 6, Issue 3, pg 108 -111,;www.pieb.cz.

6. Nguyen, A.N., Taylor, J \& Bradley, S., (2003), Relative pay and employee satisfaction: some new evidence. https.mpra.ub.uni-muenchen.de/1382,01 (43).

7. Gill, A., Sharma, S. P., Mathur, N., \& Bhutani, S. (2012). The effects of job satisfaction and work experience on employee-desire for empowerment: A comparative study in Canada and India. International Journal Of Management, 29, 190-200.

8. Bhandari, K., \& Soni, H. (2015). Impact of Gender, Age and Work Experience on Satisfaction. IOSR Journal of Business and Management, 17 (3), 48-53.

9. Indian Journal of Banking Review. Vol 24. No. 2.

10. Singh. G. Janak and Namita Dewans (2003): "Job satisfaction among bank employees.

11. Keller, (2008), Satisfaction from job facilities, Journal of IMS group, $5(1)$.

12.Singh, S., \& Tewari, V. (2011). Realtionship between motivation and job satisfaction of white collar employees:a case study. Management insights, 7 (2).

\section{AUTHORS PROFILE}

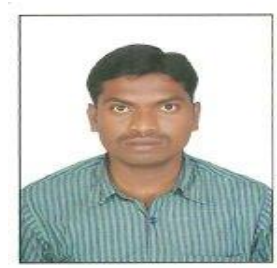

Mr. Obulesu Varikunta, Designation Research Scholar of MBA JNTU Anantapur, Qualification: M.B.A, (Ph.D.). he is completed Post graduation(MBA) in the year of 2011 Srikrishna deveraya University Anantapur, Experience : Overall Teaching Experience is 6 years, Industry experience is 1 year, and Research experience is 2 years, Publications: International journals:3 National journals:1, CONFERENCES :International : 1 National : 1 Research Areas : Human Resource Management, Stream of Lecturing : H.R.M, Management science, Managerial Economics, Strategic Management. $\mathrm{He}$ is organized Management meet in the year of 2016 at AIMS College Allagadda, He is Attend the Data Analysis workshop at Bharatiar University Coimbatore, and his presently Research Scholar in the University of JNTUA Ananthapuram. A.P India.

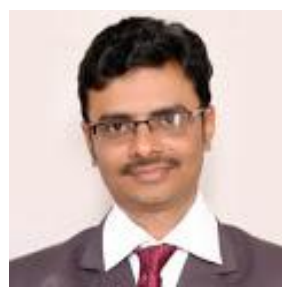

Dr. M.SUDHEER KUMAR, Designation: PROFESSOR in Department of MBA, RAJEEV GANDHI MEMORIAL COLLEGE OF ENGG $\&$ TECH (Autonomous).NANDYAL Experience : Overall Teaching Experience is 12 years and Industry experience is 1 year, and Research experience is 2 years, Publications: International journals:11 National journals:5, CONFERENCES :International : 9 National : 3 Research Areas : Marketing Management and Human Resource Management, Stream of Lecturing : Marketing Management, H.R.M, Management science, Strategic Management. He is organizing the Management meet in 2016, He is Organize the RGM Expo 5 time, AIMA All India Management Association - Membership, Member, Academic Council at RGM College of Egg \& Tech, Nandyal, Chairman, Board of Studies at RGM College of Egg \& Tech, Nandyal, Head Training \& Placement RGMCET. and he is Publish 2 books, presently he is Head Training and Placement RGMCET-Nandyal, A.P India.

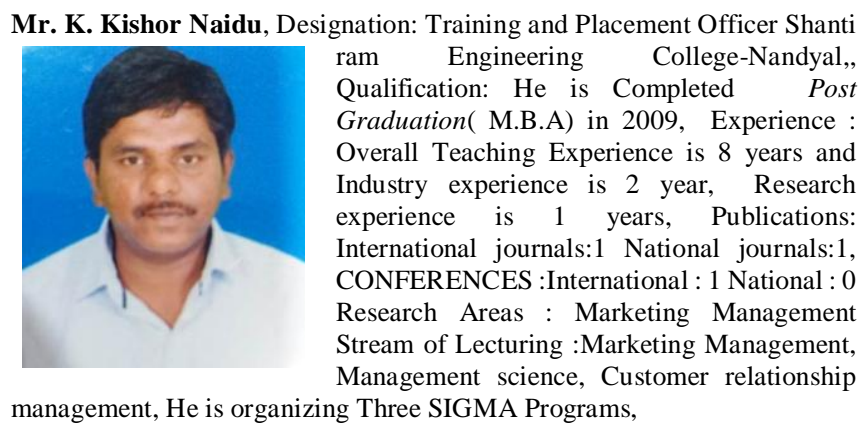
management, He is organizing Three SIGMA Programs, 